variation is analysed in terms of quantitative trait loci). This connection is a positive thing, although it is perhaps limited in scope because it may not solve what many perceive as the raison d'être of evo-devo. As Wagner says: "One of the main sources of intellectual excitement in devo-evo (sic) is the prospect of understanding major evolutionary transformations." Whether these end up being unique events or long-term accumulations of the mundane remains to be seen, but either answer will be exciting in its own way.

Overall, then, the book is a mixed bag, but contains many important contributions to the past, present and possible future of evo-devo. It is definitely a reference book rather than something to read from cover to cover. Its 'haystack' nature is off-putting at first, but the best strategy is to dive in (with the aid of the short introductory chapter) and see what you can find - including those needles that space has not permitted me to discuss.

Wallace Arthur is European editor of the journal Evolution \& Development. He is in the Department of Zoology, National University of Ireland, Galway, Ireland.

\title{
A singular view of ageing
}

\author{
Aging of the Genome: The Dual Role of \\ DNA in Life and Death \\ by Jan Vijg \\ Oxford University Press: 2007. 372 pp. \\ $£ 70, \$ 114.50$ (hbk); $€ 32.50, \$ 65$ (pbk)
}

\section{Linda Partridge}

There is no shortage of theories of ageing. Confronted by the terrifying realization of mortality, human ingenuity has created an interesting array of explanations, including toxins produced by gut bacteria (curable by eating yoghurt) and reduced secretions from the testicles (curable by transplants of testicular tissue from monkeys). There is now general agreement that ageing is caused by the accumulation of damage. Key issues are the exact types of damage responsible for functional impairment and death, and the processes that generate this damage and protect against it. Jan Vijg's excellent book Aging of the Genome makes no concession of equal space for the many candidates subject to current scrutiny. Rather, it critically examines the case for one - somatic mutation.

First formulated in the 1950s, this theory suggests a key role in ageing for the accumulation of random alterations to DNA in somatic tissues (all tissues other than the reproductive germline cells). DNA is being constantly bom- barded with chemical and physical challenges that induce random alterations, including structural damage and changes in nucleotide sequence and organization. But unlike other biomolecules, such as proteins and lipids, the damaged DNA cannot be simply broken down completely and remade, because it holds unique information. Instead, cellular pathways detect alterations and, contingent on the type of cell and the nature of the changes, this variously leads to DNA repair, arrest of the cell cycle (preventing cell division), cellular senescence or death, or toleration of the change. In some cell types, some forms of DNA alterations accumulate with age, with evidence for genomic hotspots and considerable variation between individuals. Cancer is a clear case where DNA alterations can give rise to age-related pathology; their role in other aspects of functional decline is less clear, with the exception of mutations in DNA within mitochondria, the organelles that power cells. As well as leading to ageing directly, DNA alterations could lead to ageing as a result of cellular defence mechanisms, such as selective cell death, although there is little evidence for this.

Vijg gives a clear and thoughtful account of this complex, and potentially confusing, body of work and its limitations: little work has been done on non-dividing cells; most evidence has come from cells in dishes rather than in tissues; measuring DNA alterations is difficult; a net change in levels of DNA alterations can be attributable to several different events including

\section{EXHIBITION}

\section{A painful pleasure}

Three bodies writhe in agony. Their limbs are distorted, their features unrecognizable, their entrails burst out. The Crucifixion triptych by Francis Bacon (the central panel of which is shown here) had no religious meaning for the painter, for whom the work was simply about the expression of extreme sensation. In Tiepolo's painting of the martyrdom of Saint Agatha, the young woman's ecstatic gaze is thrown heavenwards as she awaits the blow of her tormenter's sword. These two paintings are the artistic highlights of the exhibition Schmerz (Pain), which runs until 5 August at the Medical History Museum of Humboldt University and the neighbouring Hamburger Bahnhof Museum in Berlin.

The exhibition brings together artistic and medical views of pain. Opposite Bacon's Crucifixion is a glass cabinet containing pathological preparations of organs. Under the title 'The pleasure of pain', Tiepolo's Agatha is displayed along with forensic photographs showing fatal accidents that occurred during masochistic sex. The borders between art and documentation begin to blur, which makes the exhibits all the more disturbing. Video interviews with people who self-mutilate, by German film director Valenska Griesebach, could easily be from the files of a psychiatrist. And what differentiates a display in a vitrine from a pathology lab or an art installation?

The exhibition aims to show pain in all its forms, rather than to understand it, and plays with superficial similarities between different depictions. A video by Bruce Naumanns in which a violin string is repeatedly plucked appears next to chattering patch-clamp recordings in the only exhibit that gives a nod to neurophysiological research on pain. That's not enough to justify

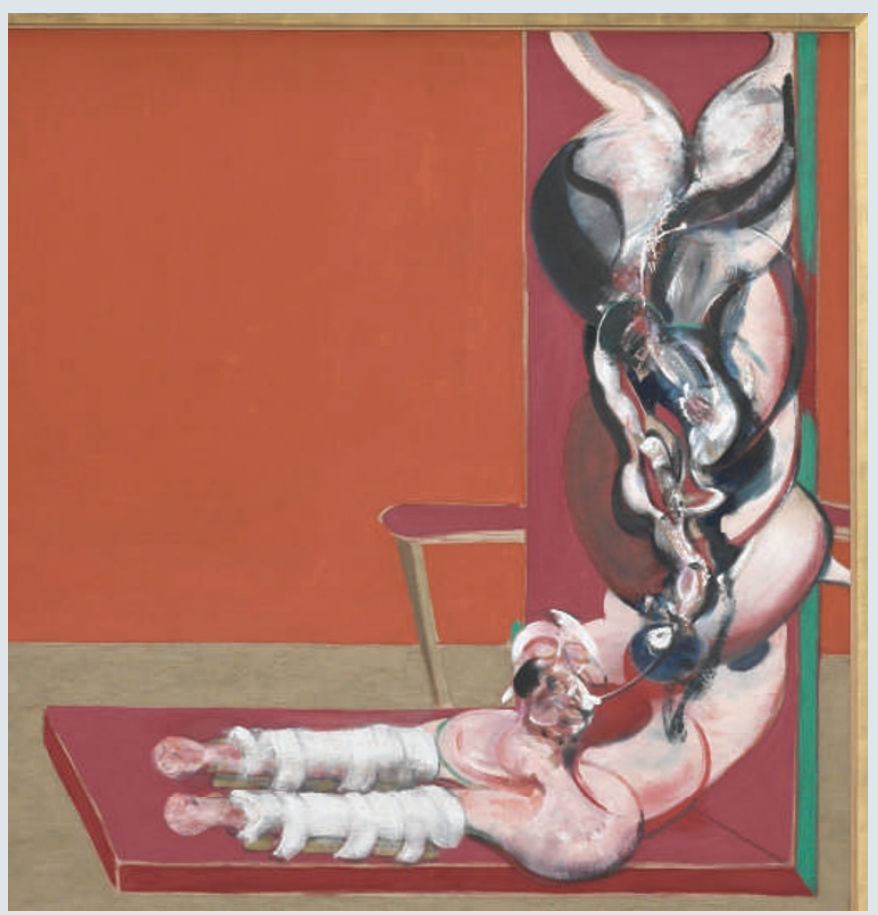

the exhibition's claim to build a bridge between science and art. Rather, wandering through this labyrinth of abominations, the question that comes most immediately to mind is why Christianity really needed to glorify this most ugly of all human sensations into the pinnacle of mystical experience. Stefan Klein 